\title{
Abundant and Stable Char Residues in Soils: Implications for Soil Fertility and Carbon Sequestration
}

\author{
J.-D. Mao, ${ }^{\dagger}$ R. L. Johnson, ${ }^{\ddagger}$ J. Lehmann, ${ }^{\S}$ D. C. Olk, ${ }^{\|}$E. G. Neves, ${ }^{\perp}$ M. L. Thompson, ${ }^{*, \#}$ \\ and K. Schmidt-Rohr, ${ }^{*}$ \\ ${ }^{\dagger}$ Department of Chemistry and Biochemistry, Old Dominion University, Norfolk, Virginia 23529, United States \\ ${ }^{\ddagger}$ Department of Chemistry, Iowa State University, Ames, Iowa 50011, United States \\ ${ }^{\S}$ Department of Crop and Soil Sciences, Cornell University, Ithaca, New York 14853, United States \\ "USDA-ARS, National Laboratory for Agriculture and the Environment, Ames, Iowa 50011, United States \\ ${ }^{\perp}$ Museu de Arqueologia e Etnologia, Universidade de Sao Paulo, Sao Paulo, SP, 05508-900 Brazil \\ \# Department of Agronomy, Iowa State University, Ames, Iowa 50011, United States
}

\section{Supporting Information}

ABSTRACT: Large-scale soil application of biochar may enhance soil fertility, increasing crop production for the growing human population, while also sequestering atmospheric carbon. But reaching these beneficial outcomes requires an understanding of the relationships among biochar's structure, stability, and contribution to soil fertility. Using quantitative ${ }^{13} \mathrm{C}$ nuclear magnetic resonance (NMR) spectroscopy, we show that Terra Preta soils (fertile anthropogenic dark earths in Amazonia that were enriched with char $>800$ years ago) consist predominantly of char residues composed of $\sim 6$ fused aromatic rings substituted by $\mathrm{COO}^{-}$groups that significantly increase the soils' cation-exchange capacity and thus the retention of plant nutrients. We also show that highly productive, grassland-derived soils in the U.S. (Mollisols) contain char (generated by presettlement fires) that is structurally comparable to char in the Terra Preta soils and much more abundant than previously thought ( 40$50 \%$ of organic C). Our findings indicate that these oxidized char residues represent a particularly stable, abundant, and fertilityenhancing form of soil organic matter.

\section{INTRODUCTION}

Feeding the $\sim 9$ billion people expected on Earth by 2050 will require a number of coordinated agricultural, economic, and social strategies, including changes in the nutrient management of cultivated soils to increase crop production. ${ }^{1,2}$ Application of biochar to soils on a large scale has been proposed as a method to increase food security by enhancing soil fertility, while at the same time sequestering carbon from the atmosphere. ${ }^{3-6}$ Bringing this approach to fruition requires an understanding of the relations among the structure of biochars, their stability, and their contribution to soil fertility. Although a global soil survey using mid-infrared analysis has shown evidence of black carbon in soils of all climate zones, ${ }^{7}$ apart from their high aromaticity, relatively little is known about the chemical structure of char residues ${ }^{8,9}$ in soils.

Amazonian Terra Preta soils are anthropogenic dark earths that were enriched with char $>800$ years ago; they are more fertile than surrounding soils that received little char input. ${ }^{10-12}$ Other, more common, fertile and char-containing soils are Mollisols. These grassland-derived soils are extensive in central North America, Ukraine, the Russian Federation, Argentina, and Uruguay, and they contribute a significant fraction of global grain production. In the World Reference Base for Soil Resources, these soils are typically classified as Phaeozems, Chernozems, and Kastanozems. ${ }^{13}$ Char in these soils has been widely attributed to grassland fires; ${ }^{14}$ in North America, such presettlement fires are well documented. ${ }^{15}$

In both Terra Preta soils and North American Mollisols, NMR studies have confirmed the presence of char residues. ${ }^{16-19}$ For example, aromaticity values estimated by extended X-ray absorption fine structure (EXAFS) and nonquantitative cross-polarization NMR previously suggested that char accounts for $\sim 25-50 \%$ of organic carbon in Terra Preta soils. ${ }^{19}$ Here, using quantitative ${ }^{13} \mathrm{C}$ NMR and NMR size measurements, ${ }^{20,21}$ we show that a much larger fraction of the organic carbon in both kinds of soils consists of oxidized char residues that are composed of fused aromatic rings substituted by $\mathrm{COO}^{-}$groups. Despite contrasting soil environments, the chemical structures of the char residues are similar. Our findings suggest that oxidized char residues containing $\sim 6$ fused aromatic rings and 5 carboxyl groups are particularly stable in soil environments and contribute to soil fertility by accounting for a significant fraction of the cation-exchange capacity. These insights have implications for both carbon sequestration in soils and large-scale production of biochars for soil application.

Received: March 21, 2012

Revised: July 13, 2012

Accepted: July 27, 2012

Published: July 27, 2012 


\section{MATERIALS AND METHODS}

Soil Samples. Terra Preta soil samples were collected from archeological sites in the central Amazon near Manaus, Brazil, as described previously. ${ }^{19}$ Samples from horizons at depths of 43-69 and 43-67 cm at the Hatahara and Lago Grande sites, respectively, were studied by NMR after demineralization by treatment with $2 \%$ HF solution (w/v) for NMR analysis. ${ }^{19}$ As a result of the acid treatment, most of the COO groups in the samples studied by NMR were protonated. The observed COO chemical shift of $170.5 \mathrm{ppm}$ and the $\mathrm{COOH}$ proton signal in the ${ }^{1} \mathrm{H}-{ }^{13} \mathrm{C}$ correlation spectrum of Figure $\mathrm{S} 1$ (Supporting Information) support this conclusion. ${ }^{16}$ Combustion analysis showed that the (partially) demineralized Hatahara Terra Preta sample consisted of $86.7 \%$ ash, $12.3 \pm 0.1 \% \mathrm{C}, 0.6 \pm 0.2 \% \mathrm{H}$, and $0.4 \pm 0.05 \% \mathrm{~N}$ by weight. The Maxfield soil sample (5-15 $\mathrm{cm}$ sampling depth) was collected in Greene County, Iowa, and was demineralized by HF with heating. ${ }^{16}$ The Zook sample (0$20 \mathrm{~cm}$ sampling depth) was collected in Story County, Iowa, and humic acid was extracted by standard procedures. ${ }^{22}$

Solid-State ${ }^{13} \mathrm{C}$ NMR Spectroscopy. The spectroscopy was performed at $100 \mathrm{MHz}$ using a Bruker DSX400 spectrometer and a Bruker 4-mm ${ }^{1} \mathrm{H}-{ }^{13} \mathrm{C}$ double-resonance MAS probe head. Samples were packed into 4-mm diameter zirconia rotors with 5-mm long glass inserts at the bottom to constrain the samples to the space within the radio frequency coil. The mass of each sample was recorded for quantification of ${ }^{13} \mathrm{C}$ observability. The ${ }^{13} \mathrm{C}$ chemical shifts were referenced to tetramethylsilane using the $\mathrm{COO}^{-}$resonance of glycine at $176.49 \mathrm{ppm}$ as a secondary reference. The $90^{\circ}$ pulse length was $4 \mu \mathrm{s}$. The recycle delay was $40 \mathrm{~s}$ for Hatahara and $26 \mathrm{~s}$ for Lago Grande, which is $>4$ times the measured spin-lattice relaxation time $^{23,24}$ (see also Figure S2 in the Supporting Information). A spectrum with 100-s recycle delay experiments confirmed complete relaxation, as did $>95 \%$ observability in spin counting analysis. The fully relaxed ${ }^{13} \mathrm{C}$ spectrum of Zook soil humic acid extract was measured with a 100-s and that of the Maxfield organic matter with a 50-s recycle delay.

The quantitative direct-polarization ${ }^{13} \mathrm{C}$ NMR spectra were recorded at $14 \mathrm{kHz}$ MAS, which avoids the overlap of aromatic spinning sidebands with alkyl peaks that has plagued several previous NMR studies of chars and highly aromatic soil organic matter. A Hahn spin echo was generated before detection to avoid baseline distortions due to pulse dead time. ${ }^{25}{ }^{1} \mathrm{H}$ decoupling of sufficiently high-power $\left(\left|\gamma \mathrm{B}_{1}\right|=2 \pi 70 \mathrm{kHz}\right)$ with two-pulse phase modulation (TPPM) ${ }^{26}$ was applied during detection. Carbon observability was determined to be $>95 \%$ by comparison of the total ${ }^{13} \mathrm{C}$ NMR signal with that of a polystyrene standard, per scan and $\mathrm{mg}$ C. In addition, for each sample, a corresponding quantitative spectrum of nonprotonated and methyl carbons, obtained after $68 \mu$ s of recoupled dipolar dephasing, ${ }^{25}$ was also recorded. By combining dipolar dephasing with direct polarization experiments, we obtained separate quantitative spectra of nonprotonated aromatic carbon and those of protonated aromatics by difference.

To estimate the size of fused aromatic rings, recoupled ${ }^{1} \mathrm{H}-{ }^{13} \mathrm{C}$ dipolar dephasing ${ }^{21}$ was applied, with two ${ }^{1} \mathrm{H} 180^{\circ}$ pulses per rotation period that prevent magic angle spinning from averaging out weak ${ }^{1} \mathrm{H}-{ }^{13} \mathrm{C}$ dipolar couplings. In order to detect nonprotonated carbons with good relative efficiency, direct polarization/total sideband suppression (DP/TOSS) was used at a spinning speed of $7 \mathrm{kHz}$. The signal of nonprotonated C, selected by $40 \mu$ s of regular gated decoupling, between 107 and $142 \mathrm{ppm}$ was considered in the analysis. The dipolar dephasing times varied from 0.29 to $1.7 \mathrm{~ms}$

\section{RESULTS}

NMR Spectroscopy and Structural Analysis of Char in Soils. Our findings are enabled by the analysis of whole soil organic matter using quantitative direct polarization (DP) ${ }^{13} \mathrm{C}$ NMR. With sufficiently long recycle delays and fast magic-angle spinning (MAS), DP ${ }^{13} \mathrm{C}$ NMR provides the aromatic peaks of char at full intensity. This avoids the reduction of signals from larger aromatic clusters that has affected previous NMR studies that relied on cross-polarization (CP) from ${ }^{1} \mathrm{H},{ }^{19,27}$ which inefficiently detects carbon atoms in the core of fused aromatic rings in char. ${ }^{28}$ In addition, we have applied advanced NMR techniques for estimating the size of the clusters of fused aromatic rings. ${ }^{20}$

Figure 1a, b shows the quantitative DP solid-state ${ }^{13} \mathrm{C}$ NMR spectra of the organic carbon from the ca. 0.4 to $0.7 \mathrm{~m}$ deep

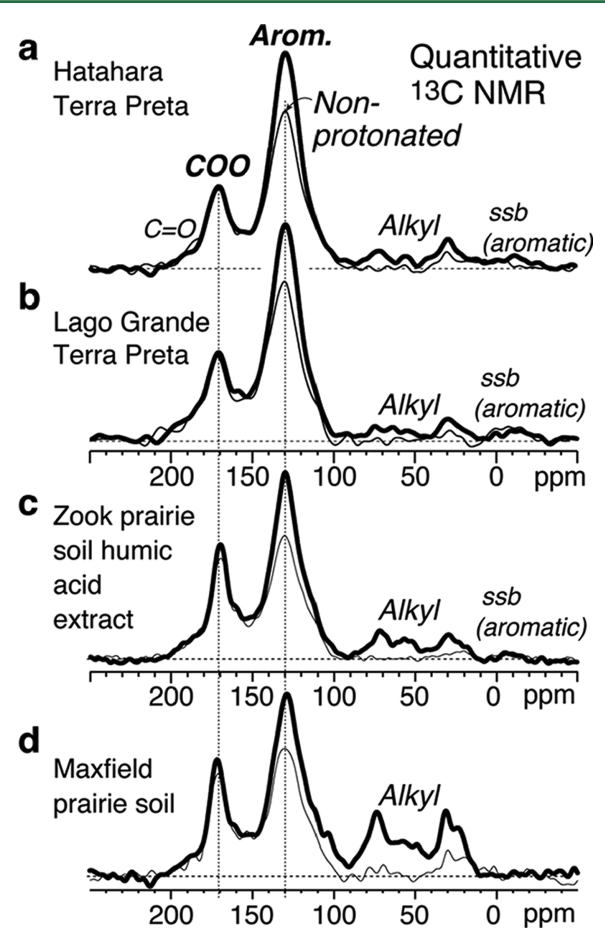

Figure 1. Quantitative, direct polarization ${ }^{13} \mathrm{C}$ NMR spectra of Terra Preta soil organic matter (HF-treated) from two sites (a) Hatahara and (b) Lago Grande. Thick line: spectrum of all carbons; thin line: spectrum of nonprotonated $\mathrm{C}$ and of $\mathrm{CH}_{3}$. (c, d) Corresponding spectra of Iowa prairie soil organic matter: (c) humic acid extract of Zook soil and (d) unfractionated organic matter of Maxfield soil. The spectra were obtained at a resonance frequency of $100 \mathrm{MHz}$ with 14$\mathrm{kHz}$ magic-angle spinning. Spinning sidebands of the aromatic peaks are labeled "ssb (aromatic)" and were included in the tally of the total aromatic signal.

horizons of two Brazilian Terra Preta soils. ${ }^{19,27}$ (To isolate char-rich materials, we avoided surface horizons that were enriched with younger organic matter.) The spectra are dominated by aromatic-carbon peaks around $130 \mathrm{ppm}$ and signals of COO groups near $170 \mathrm{ppm}$. The spectra of carbons not bonded to hydrogen (thin lines in Figure 1) show that most of the aromatic carbons are not protonated and resonate near $130 \mathrm{ppm}$, which is characteristic of fused aromatic rings as found in char, ${ }^{20}$ while nonprotonated carbons of substituted 
Table 1. Quantitative ${ }^{13} \mathrm{C}$ NMR Spectral Analysis of (Top) Organic C in Two Terra Preta Soils (Averaged, since the Data Differ by $\leq 1 \%$ ), Followed by a Possible Distribution into Contributions from Low-Alkyl Char Residues and from Typical Soil Organic Carbon Not Derived from Char (With an Aromaticity of 25\%)

\begin{tabular}{|c|c|c|c|c|c|c|c|c|c|}
\hline \multirow[b]{2}{*}{ moieties } & \multicolumn{2}{|c|}{ carbonyls } & \multicolumn{3}{|c|}{ aromatics } & \multicolumn{3}{|c|}{ alkyls } & \multirow[b]{2}{*}{ total } \\
\hline & $\mathrm{C}=\mathrm{O}$ & $\mathrm{COOH}$ & $\mathrm{C}-\mathrm{O}-\mathrm{H} / \mathrm{C}$ & $\mathrm{C}_{\text {nonpro }}$ & $\mathrm{C}-\mathrm{H}$ & $\mathrm{HCOH}^{a}$ & $\mathrm{CH}_{2} / \mathrm{CH}$ & $\mathrm{CH}_{3}$ & \\
\hline ppm & $210-183$ & $183-160$ & $160-145$ & $145-97$ & & $97-50$ & $50-25$ & $25-7$ & \\
\hline Terra Preta & 4 & 17 & 8 & 48 & 13 & 5 & 3 & 2 & $100 \%$ \\
\hline Terra Preta char residue & 3.5 & 15 & 7 & 47 & 12 & 1 & 1 & 1 & $88 \%$ \\
\hline Terra Preta soil org. C & 0.5 & 2 & 1 & 1 & 1 & 4 & 2 & 1 & $12 \%$ \\
\hline Endoaquoll & 2 & 16 & 7 & 34 & 11 & 18 & 8 & 4 & $100 \%$ \\
\hline Endoaquoll char residue & 1 & 7 & 3.5 & 31 & 7 & 1 & 1 & 0.5 & $52 \%$ \\
\hline Endoaquoll soil org. C & 1 & 9 & 3.5 & 3 & 4 & 17 & 7 & 3.5 & $48 \%$ \\
\hline
\end{tabular}

${ }^{a}$ Anomeric $(\mathrm{O}-\mathrm{C}-\mathrm{O}$ alkyl) carbons have been included here $(1 / 6$ of this intensity). This chemical-shift range also includes $\mathrm{HCNH}$ of peptides.

${ }^{b}$ Bottom rows: The same for Iowa Endoaquolls (based on averaged data of Maxfield Mollisol and Webster soil organic matter from ref 16). Intensities have been corrected for residual spinning sidebands. Error margins: $\pm 2 \%$.

single benzene rings give signals around $150 \mathrm{ppm}$ (aromatic $\mathrm{C}-\mathrm{O}$ ), $133 \mathrm{ppm}$ (aromatic C-C), and $<125 \mathrm{ppm}$ (aromatic C two bonds from $\mathrm{O}$ or $\mathrm{N}) .^{25,29}$ The signals of all types of alkyl carbons, between 97 and 7 ppm, are quite negligible ( $\sim 9 \%$ of the total spectral area, see Table 1). This indicates that carbon not derived from char represents only a small fraction of the organic carbon in these horizons, and it is consistent with the low $\mathrm{H}$ :C ratios (ca. 0.6:1) in these samples. In fact, the $\mathrm{H}: \mathrm{C}$ ratio can be calculated from the data in Table $1,{ }^{23}$ if we assume that $80 \pm 20 \%$ of the COO groups are protonated (due to the $\mathrm{HF}$ treatment; this is consistent with the strong $\mathrm{COOH}$ signal in ${ }^{1} \mathrm{H}-{ }^{13} \mathrm{C}$ heteronuclear correlation NMR, see Figure S1) and that half of the aromatic $\mathrm{C}-\mathrm{O}$ are phenols $(\mathrm{C}-\mathrm{OH})$. This analysis yields an $\mathrm{H}$ : $\mathrm{C}$ ratio of $0.51 \pm 0.05$, consistent with the experimental value of $0.58 \pm 0.19$.

Table 1 shows that $\sim 20 \%$ of all Terra Preta carbon is in $\mathrm{COO}$ or $\mathrm{C}=\mathrm{O}$ groups, while alkyl $\mathrm{C}$ accounts for only $10 \%$. No compound of high molecular weight exists that consists predominantly of COO groups. (This would be different for $\mathrm{CH}_{2}$ groups (n-alkanes and polyethylene are mostly $\mathrm{CH}_{2}$ ), $\mathrm{HCOH}$ (polysaccharides), and aromatic $\mathrm{C}$ (graphite and char)). Therefore, the $\mathrm{COO}$ groups must be bonded to alkyl or aromatic carbons.

The amount of alkyl C is too small $(\sim 10 \%)$ to support all of the $\mathrm{COO}(17 \%)$ groups. For $\mathrm{HCOH}$ carbons (polysaccharides) and for $\mathrm{NCH}$ (peptides), which account for half of the alkyl C (see Table 1), there are usually at least two alkyl carbons per $\mathrm{COO}$ group. It is interesting to note that $\mathrm{CH}_{2}$ and $\mathrm{CH}_{3}$ groups, which necessarily have several bonds saturated by $\mathrm{H}$, cannot support many $\mathrm{COO}$ groups in a structure of significant molecular weight. In this context, it is relevant that we have previously shown, by $\mathrm{NMR}$, that esters are rare in Mollisol organic matter. ${ }^{16}$ So most $\mathrm{COO}$ groups are end groups.

Thus, the maximum number of COO groups that can be supported by the alkyl residues is $10 \% / 2$, which is less than $1 / 3$ of the total (16.5\%). Even this is probably too high; the COO peak in soil organic matter rarely reaches more than $1 / 4$ of the total spectral area. Some COO groups bonded to alkyl carbons, attributed to organic matter not derived from char, do exist in Terra Preta. In our analysis (see Table 1, third row), we propose that this is $2 \%$ out of $17 \%$.

Substantial bonding of the $\mathrm{COO}^{-}$groups, resonating at 170 ppm, to aromatic rings is confirmed by ${ }^{1} \mathrm{H}-{ }^{13} \mathrm{C}$ heteronuclear correlation NMR (see Figure S1), which shows that the $\mathrm{COO}^{-}$ groups are close to aromatic protons. The conclusion that
$\mathrm{COO}^{-}$groups are associated with aromatic rings has also been drawn from multivariate curve resolution analysis of (nonquantitative) ${ }^{13} \mathrm{C}$ NMR spectra of Terra Preta humic acid extracts. ${ }^{30}$ The $\mathrm{C}=\mathrm{O}$ groups, with their chemical shifts $<200$ $\mathrm{ppm}$, must also be bonded to aromatic rings, since alkyl-bonded $\mathrm{C}=\mathrm{O}$ resonates at $>200$ ppm. $^{31}$

Table 1 shows that $\geq 90 \%$ of all carbons in our Terra Preta samples are found in aromatic rings or in $\mathrm{COO}^{-}$and $\mathrm{C}=\mathrm{O}$ groups mostly bonded to aromatic rings. While a small fraction $(\sim 6 \%)$ of the aromatic $\mathrm{C}$ will be from soil organic carbon not derived from char, some of the alkyl segments probably do belong to the char, given that $3-6 \%$ of synthetic pyrolysis chars are alkyl moieties. ${ }^{20}$ Table 1 shows the distribution of carbon in the Terra Preta samples into $88 \%$ char residues and $12 \%$ other organic matter of moderate aromaticity. These results are particularly meaningful since they were obtained from whole organic matter rather than merely humic extracts ${ }^{19,27,30}$ that represent only a fraction of all soil carbon. The abundant $\mathrm{COO}^{-}$groups are probably the remnants of aromatic rings that have been oxidized, similar to the COO groups attached to aromatic rings that are formed by chemical oxidation of char in controlled laboratory experiments. ${ }^{32}$

The spectral pattern of $\mathrm{COO}^{-}$and $\mathrm{C}=\mathrm{O}$ substituted aromatic rings revealed in ${ }^{13} \mathrm{C}$ NMR of Terra Preta organic carbon can also be recognized in the spectra of organic matter of temperate-region grassland soils, though with a larger background of nonchar organic carbon. ${ }^{16,22,33,34}$ This is exemplified in Figure 1c, which shows the ${ }^{13} \mathrm{C}$ NMR spectrum of a humic acid extract from the surface horizon of an Iowa Mollisol (Zook, a Cumulic Vertic Endoaquoll). ${ }^{22}$ Counting the nonprotonated cores and the substituted or protonated edges of the aromatic clusters, as well as the $\mathrm{COO}$ and $\mathrm{C}=\mathrm{O}$ groups bonded to them, oxidized char residues represent $67 \pm 9 \%$ of all carbon in the Mollisol humic acid extract (see Table S1, Supporting Information). While the humic acid extract is not fully representative of the parent organic matter, it allows the spectra of these char-derived structures to be detected with less background, since the extraction concentrates the char-derived carboxyl groups and associated fused aromatic rings.

Quantitative char contents can be estimated from the ${ }^{13} \mathrm{C}$ NMR spectra of the organic carbon of an unfractionated, poorly drained Mollisol (Maxfield, a Typic Endoaquoll) in Iowa, ${ }^{16}$ see Figure $1 \mathrm{~d}$, which are also dominated by $\mathrm{COO}$ and aromaticcarbon peaks. Again, the low chemical shifts of the $\mathrm{C}=\mathrm{O}$ groups indicate their bonding to aromatic rings. The 
quantitative distribution of functional groups shows that $52 \pm$ $11 \%$ of carbon occurs in oxidized char residues (Table 1); the corresponding estimate for two better drained Argiudolls in the same Iowa landscape is $44 \pm 12 \% .^{16}$

These values exceed those of other studies that have used less quantitative methods. For example, using a benzene polycarboxylic acid method, one international study reported that char residues accounted for a minimum of $4-30 \%$ of soil organic carbon in 27 studied Mollisols. ${ }^{14}$ They are also considerably greater than values (4-18\%) estimated in a climosequence of North American primarily short-grass prairie soils using the benzene polycarboxylic acid approach, which provides only a relative measure of the pyrogenic carbon content of a soil. ${ }^{35}$ Our values are also generally higher than the values of 4-45\% (average for 11 horizons: 19\%) estimated for German chernozemic soils from nonquantitative CP NMR (with an unspecified "empirically determined correction"). ${ }^{17}$ Finally, they are greater than the char content of $26 \%$ estimated for an Australian Mollisol using UV photooxidation and DP NMR with relatively slow magic-angle spinning, where aromatic spinning sidebands overlap with alkyl resonances. ${ }^{18}$ The previous NMR estimates are lower in part because the aromatic carbons resonating at $<110 \mathrm{ppm}$ and the $\mathrm{COO}$ and $\mathrm{C}=\mathrm{O}$ groups bonded to the fused aromatic rings were not included in the char fraction, even though it was recognized that the spectra of the char residues after photooxidation showed pronounced COO resonances. ${ }^{18}$

Our observations are very consistent with the conclusions of radiocarbon dating studies that about one-half of the nearsurface soil organic carbon of North American grassland soils consists of a stable pool with a mean residence time on the order of 1000-2000 years BP. ${ }^{36}$ In the older literature, that stable pool was associated with the (empirically defined) humic acid fraction ${ }^{37}$ and indeed the extracted humic acid extract in our study was found to be enriched in oxidized char residues.

Significant condensation of the aromatic rings, a hallmark of char-derived material, ${ }^{20}$ is indicated by the large signal fraction ( $81 \%$ for the Terra Preta soils) of nonprotonated aromatic C remaining after ${ }^{1} \mathrm{H}-{ }^{13} \mathrm{C}$ dipolar dephasing (thin lines in Figure 1). By tallying up all the aromatic $\mathrm{C}$ that must be at the edge of aromatic rings ${ }^{20}$ (aromatic $\mathrm{C}-\mathrm{H}$, aromatic $\mathrm{C}-\mathrm{O}$, aromatic $\mathrm{C}$ $(\mathrm{C}=\mathrm{O}$ or $\mathrm{COO})$, and aromatic $\mathrm{C}$-alkyl, assuming the average alkyl substituent to contain two carbons), we can estimate the aromatic edge fraction, $\chi_{\text {edge }}{ }^{20}$ This value provides a stringent lower limit, $n_{\min }=6 / \chi_{\text {edge }} 2$, to the number of carbons in an aromatic cluster. ${ }^{20}$ For the Terra Preta char residues (second row in Table 1), the aromaticity (including aromatic $\mathrm{C}-\mathrm{O}$ ) is $66 / 88=75 \pm 3 \%$, and $\chi_{\text {edge }}=0.58 \pm 0.04$. From $\chi_{\text {edge }} \leq 0.62$, we calculate that at least $n_{\min }=16$ carbons are in the typical aromatic cluster derived from char. Adding one $\mathrm{C}=\mathrm{O} / \mathrm{COO}$ substituent per every four aromatic carbons (from Table 1: (3.5 $+14.5) \% / 0.655=26 \%)$ results in a total of at least 20 carbons in the typical cluster.

The size of the aromatic clusters can also be estimated based on NMR experiments probing the ${ }^{1} \mathrm{H}-{ }^{13} \mathrm{C}$ dipolar couplings, which depend strongly $\left(\sim 1 / r^{3}\right)$ on the ${ }^{1} \mathrm{H}-{ }^{13} \mathrm{C}$ internuclear distance $r$. Figure 2 shows recoupled ${ }^{1} \mathrm{H}-{ }^{13} \mathrm{C}$ dipolar dephasing ${ }^{21}$ of the nonprotonated nonpolar aromatic signals of Terra Preta soil organic carbon, of the humic acid extract from the Zook Iowa prairie soil, and of whole organic matter from the Maxfield Iowa prairie soil. These are compared with published reference data from several types of fresh char as well as lignin. ${ }^{20}$ Slower dephasing reflects weaker dipolar fields of

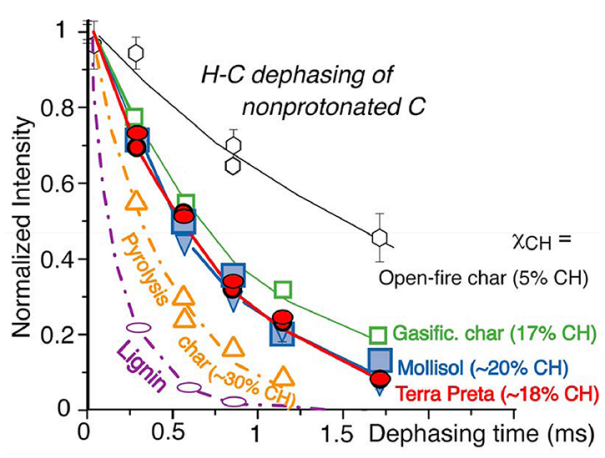

Figure 2. Size determination of aromatic clusters in Terra Preta soil organic matter (red filled ovals: Hatahara site; filled circles: Lago Grande site) as well as prairie-soil (Mollisol) humic acid extract (Zook, blue filled inverted triangles) and whole organic matter (Maxfield soil, blue filled squares) by long-range ${ }^{1} \mathrm{H}-{ }^{13} \mathrm{C}$ dipolar dephasing NMR. The normalized integral intensity of the nonprotonated aromatic carbon signal between 107 and $142 \mathrm{ppm}$ is plotted as a function of the recoupled $\mathrm{H}-\mathrm{C}$ dipolar dephasing time. For reference, data are also shown for open-fire grass char (open hexagons), gasification char (open squares), pyrolysis char (open triangles), and lignin (open ellipses) (from ref 20). The fraction of aromatic char carbons that are protonated is listed for each sample.

the ${ }^{1} \mathrm{H}$ nuclear magnets experienced by the ${ }^{13} \mathrm{C}$ spins, which is the hallmark of larger aromatic clusters. The dephasing of the Terra Preta signal intensity is rather slow, which excludes linear condensation of the aromatic rings. ${ }^{21}$ The data for the Terra Preta organic carbon, the Iowa prairie soil organic carbon, and the Iowa soil humic acid extract are strikingly similar, which underlines the similarity between the oxidized char residues in these relatively fertile tropical and temperate-region soils.

\section{DISCUSSION}

Based on the NMR composition and $\mathrm{H}-\mathrm{C}$ distance data, a structural model for a typical aromatic ring system in the Terra Preta and temperate grassland soils can be proposed (Figure 3);

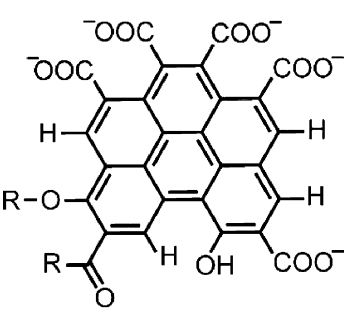

Figure 3. Model of a typical stable and fertile aromatic cluster in Terra Preta and temperate grassland soils, derived from NMR spectroscopy and $\mathrm{H}-\mathrm{C}$ distance measurements.

a more complex model also consistent with the data is shown in Figure S3. A typical cluster consists of 5-10 aromatic rings heavily substituted with $\mathrm{COO}^{-}$groups, which impart to the char residue a large cation exchange capacity ${ }^{27,38}$ and make it hydrophilic, both favorable features for soil fertility. Soil fertility is a composite of many soil properties, but cation exchange capacity is surely one of the most important.

Impact of Char Residues on Cation Exchange Capacity. We estimate that char $\mathrm{COO}^{-}$groups can account for essentially the entire contribution of organic matter to the $\mathrm{pH}-7$ cation exchange capacity (CEC) of the Iowa Mollisols. The CEC of soil is derived from both permanent charges 
associated with clay-size layer silicates and the $\mathrm{pH}$-dependent charges of organic matter. Unfortunately, the unique contribution of organic matter to CEC is difficult to determine since clay and organic matter are typically aggregated. Methods to measure one in the absence of the other inevitably must destroy the aggregates, creating artifact surfaces and exchange sites. Moreover, standard multiple regression approaches must account for the usual positive correlation between clay and organic matter concentrations in soil - a correlation that limits the confidence with which the organic matter contribution can be strictly assessed. To overcome these problems, Thompson et al. $^{39}$ used principal components analysis to estimate the unique contribution of soil organic carbon (SOC) to the CEC of silt and clay fractions of a suite of central-Iowa soil horizons. The contribution of SOC to CEC at $\mathrm{pH} 7$ was determined to be 559 $\mathrm{cmol}(-) \mathrm{kg}^{-1}$ SOC. In the present investigation, we have concluded that the functional units of char in Iowa Mollisols are comprised of about 5 moles of $\mathrm{COO}^{-}$per 30 moles of $\mathrm{C}$ (Figure 3), which would account for $1390 \mathrm{cmol}(-) \mathrm{kg}^{-1}$ char C. Thus, if just $40 \%$ of a soil's organic carbon were composed of char (a low estimate for the Mollisols we have investigated see Tables 1 and S1), essentially the entire contribution of organic matter to the soil's CEC could be attributed to the CEC of the char component $\left[\left(0.40 \mathrm{~kg}\right.\right.$ char $\left.\mathrm{C} \mathrm{kg}^{-1} \mathrm{SOC}\right) \times$ $\left(1390 \mathrm{cmol}(-) \mathrm{kg}^{-1}\right.$ char C $)=556 \mathrm{cmol}(-) \mathrm{kg}^{-1}$ SOC $]$.

While other studies have shown that synthetic biochars may have considerable cation exchange capacity ${ }^{40}$ and that natural char can be gradually oxidized in the soil environment, ${ }^{41,42}$ our work serves as an independent, direct, structural confirmation of the hypothesis that the large cation exchange capacity in Terra Preta soils and Iowa Mollisols is related to the high density of oxidized functional groups on the char aromatic core. ${ }^{10,38}$ The cluster size is similar to that of synthetic pyrolysis chars, but the fresh chars have far fewer $\mathrm{COO}^{-}$substituents ${ }^{20,43}$ and therefore a lower cation exchange capacity. The similarity of the structure of the char residues in both fertile tropical Terra Preta and highly fertile, temperate-region, prairie-derived soils suggests that aromatic clusters of this size and level of oxidation are stable in the soil environment and likely to enhance soil fertility.

Analyses of our NMR data reveal that the organic carbon from deeper horizons of two well-characterized Terra Preta soils consists almost completely of oxidized char residues in the form of small clusters of aromatic rings substituted by COO groups. Similarly oxidized char accounts for about half of the organic carbon in surface horizons of the investigated fertile, prairie-derived soils of Iowa, USA. These results suggest that substantial amounts of char could be incorporated into many soils with positive long-term effects on soil fertility. The proposed structure of soil char residues, together with their high abundance in the temperate-region prairie soils investigated, implies that most of the organic-matter-derived cation exchange capacity in these fertile soils is directly attributable to the abundant $\mathrm{COO}^{-}$groups in the char residues. Extensive application of locally produced or industrial biochar to soils has been proposed for its impact on Earth's carbon budget. The net agronomic impacts of such soil amendments are not yet consistently predictable across all soils or with all biochars. ${ }^{44}$ Still, our results support the potential for biochar amendments to improve soil fertility through increases in cation exchange capacity. Our findings also suggest that the fertility of charamended soils could be enhanced in the short term by partially oxidizing fresh, pyrolysis char to simulate the oxidative aging processes deduced here and in other studies. ${ }^{41,42}$

\section{ASSOCIATED CONTENT}

\section{S Supporting Information}

Proof of COO bonding to aromatic rings is provided, complete spin-lattice relaxation between scans is documented for our quantitative ${ }^{13} \mathrm{C}$ NMR spectra, a detailed quantitative analysis of the composition of Zook soil humic acid is given, and a more complex structural model also consistent with the data is presented. This material is available free of charge via the Internet at http://pubs.acs.org.

\section{AUTHOR INFORMATION}

\section{Corresponding Author}

*Phone: 515-294-6105; Fax: 515-294-0105; E-mail: srohr@ iastate.edu (K.S.-R.). Phone: 515-294-2415; Fax: 515-2943163; E-mail: mlthomps@iastate.edu (M.L.T.).

\section{Notes}

The authors declare no competing financial interest.

\section{ACKNOWLEDGMENTS}

K.S.R. and M.L.T. thank D. A. Laird, R. C. Brown, and C. E. Brewer for insightful discussions on biochar. J.D.M. thanks the NSF (EAR-0843996 and CBET-0853950) for financial support.

\section{REFERENCES}

(1) Godfray, H. C. J.; Beddington, J. R.; Crute, I. R; Haddad, L.; Lawrence, D.; Muir, J. F.; Pretty, J.; Robinson, S.; Thomas, S. M.; Toulmin, C. Food security: the challenge of feeding 9 billion people. Science 2010, 327 (5967), 812-818.

(2) Power, A. G. Ecosystem services and agriculture: tradeoffs and synergies. Philos. Trans. R. Soc., B 2010, 365 (1554), 2959-2971.

(3) Glaser, B.; Lehmann, J.; Zech, W. Ameliorating physical and chemical properties of highly weathered soils in the tropics with charcoal - a review. Biol. Fert. Soils 2002, 35 (4), 219-230.

(4) Lehmann, J. A handful of carbon. Nature 2007, 447 (7141), 143144.

(5) Laird, D. A. The charcoal vision: a win-win-win scenario for simultaneously producing bioenergy, permanently sequestering carbon, while improving soil and water quality. Agron. J. 2008, 100 (1), 178-181.

(6) Woolf, D.; Amonette, J. E.; Street-Perrott, F. A.; Lehmann, J.; Joseph, S. Sustainable biochar to mitigate global climate change. Nat. Commun. 2010, 1 (5), 56.

(7) Krull, E.; Lehmann, J.; Skjemstad, J.; Baldock, J.; Spouncer, L. The global extent of black $\mathrm{C}$ in soils: is it everywhere? In Grasslands: Ecology, Management and Restoration; Schröder, H. G., Ed.; Nova Science Publishers: 2008; pp 13-17.

(8) Goldberg, E. D. Black Carbon in the Environment; John Wiley \& Sons: New York, 1985.

(9) Schmidt, M. W. I.; Noack, A. G. Black carbon in soils and sediments: analysis, distribution, implications, and current challenges. Global Biogeochem. Cycles 2000, 14, 777-793.

(10) Glaser, B.; Haumaier, L.; Guggenberger, G.; Zech, W. The 'Terra Preta' phenomenon: a model for sustainable agriculture in the humid tropics. Naturwissenschaften 2001, 88 (1), 37-41.

(11) Lehmann, J.; Pereira da Silva, J.; Steiner, C.; Nehls, T.; Zech, W.; Glaser, B. Nutrient availability and leaching in an archaeological Anthrosol and a Ferralsol of the Central Amazon basin: fertilizer, manure and charcoal amendments. Plant Soil 2003, 249 (2), 343-357.

(12) Glaser, B. Prehistorically modified soils of central Amazonia: a model for sustainable agriculture in the twenty-first century. Philos. Trans. R. Soc., B 2007, 362, 187-196.

(13) International Union of Soil Science Working Group WRB. World Reference Base for Soil Resources 2006. FAO: Rome, 2006. 
(14) Rodionov, A.; Amelung, W.; Peinemann, N.; Haumaier, L.; Zhang, X.; Kleber, M.; Glaser, B.; Urusevskaya, I.; Zech, W. Black carbon in grassland ecosystems of the world. Global Biogeochem. Cycles 2010, 24, GB3013.

(15) Krug, E. C.; Hollinger, S. E. Identification of Factors That Aid Carbon Sequestration in Illinois Agricultural Systems; ISWS CR 2003-02; Illinois Council on Food and Agricultural Research: Champaign, IL, 2003; p 90.

(16) Fang, X.; Chua, T.; Schmidt-Rohr, K.; Thompson, M. L. Quantitative ${ }^{13} \mathrm{C}$ NMR of whole and fractionated Iowa Mollisols for assessment of organic matter composition. Geochim. Cosmochim. Acta 2010, 74 (2), 584-598.

(17) Schmidt, M. W. I.; Skjemstad, J. O.; Gehrt, E.; Kögel-Knabner, I. Charred organic carbon in German chernozemic soils. Eur. J. Soil Sci. 1999, 50, 351-365.

(18) Skjemstad, J. O.; Taylor, J. A.; Smernik, R. J. Estimation of charcoal (char) in soils. Commun. Soil Sci. Plant Anal. 1999, 30, 22832298.

(19) Solomon, D.; Lehmann, J.; Thies, J. E.; Schafer, T.; Liang, B.; Kinyangi, J.; Neves, E.; Petersen, J.; Luizao, F.; Skjemstad, J. Molecular signature and sources of biochemical recalcitrance of organic $\mathrm{C}$ in Amazonian Dark Earths. Geochim. Cosmochim. Acta 2007, 71, 22852289.

(20) Brewer, C. E.; Schmidt-Rohr, K.; Satrio, J. A.; Brown, R. C. Characterization of biochar from fast pyrolysis and gasification systems. Environ. Prog. Sustainable Energy 2009, 28 (3), 386-396.

(21) Mao, J. D.; Schmidt-Rohr, K. Recoupled long-range C-H dipolar dephasing in solid-state NMR, and its use for spectral selection of fused aromatic rings. J. Magn. Reson. 2003, 162 (1), 217-227.

(22) Mao, J.; Fang, X.; Schmidt-Rohr, K.; Carmo, A. M.; Hundal, L. S.; Thompson, M. L. Molecular-scale heterogeneity of humic acid in particle-size fractions of two Iowa soils. Geoderma 2007, 140 (1-2), $17-29$.

(23) Mao, J. D.; Hu, W. G.; Schmidt-Rohr, K.; Davies, G.; Ghabbour, E. A.; Xing, B. Quantitative characterization of humic substances by solid-state carbon-13 nuclear magnetic resonance. Soil Sci. Soc. Am. J. 2000, 64 (3), 873-884.

(24) Torchia, D. A. The measurement of proton-enhanced carbon-13 T1 values by a method which suppresses artifacts. J. Magn. Reson. 1978, 30, 613-616.

(25) Mao, J.-D.; Schmidt-Rohr, K. Accurate quantification of aromaticity and nonprotonated aromatic carbon fraction in natural organic matter by ${ }^{13} \mathrm{C}$ solid state NMR. Environ. Sci. Technol. 2004, 38, 2680-2684.

(26) Bennett, A. E.; Rienstra, C. M.; Auger, M.; Lakshmi, K. V.; Griffin, R. G. Heteronuclear decoupling in rotating solids. J. Chem. Phys. 1995, 103 (16), 6951-6958.

(27) Novotny, E. H.; deAzevedo, E. R.; Bonagamba, T. J.; Cunha, T. J.; Madari, B. E.; Benites, V. D. M.; Hayes, M. H. B. Studies of the compositions of humic acids from Amazonian Dark Earth soils. Environ. Sci. Technol. 2007, 41, 400-4005.

(28) Smernik, R. J.; Baldock, J. A.; Oades, J. M. Impact of remote protonation on 13C CPMAS NMR quantitation of charred and uncharred wood. Solid State Nucl. Magn. Reson. 2002, 22 (1), 71-82.

(29) Mao, J.-D.; Holtman, K. M.; Scott, J. T.; Kadla, J. F.; SchmidtRohr, K. Differences between lignin in unprocessed wood, milled wood, mutant wood, and extracted lignin detected by ${ }^{13} \mathrm{C}$ solid-state NMR. J. Agric. Food Chem. 2006, 54, 9677-9686.

(30) Novotny, E. H.; Hayes, M.; Madari, B. E.; Bonagamba, T.; deAzevedo, E.; de Souza, A. A.; Song, G.; Nogueira, C. M.; Mangrich, A. S. Lessons from the Terra Preta de Indios of the Amazon Region for the utilisation of charcoal for soil amendment. J. Braz. Chem. Soc. 2009, 20 (6), 1003-1010.

(31) Reich, H. J. C-13 NMR Chemical Shifts (Wisconsin data base), 2012.http://www.chem.wisc.edu/areas/reich/Handouts/nmr-c13/ cdata.htm (accessed July 6, 2012).

(32) Hammes, K.; Schmidt, M. W. I.; Smernik, R.; Currie, L. A.; Ball, W. P.; Nguyen, T. H.; Louchouran, P.; Houel, S.; Gustafsson, O.; Elmquist, M.; Cornellisen, G.; Skjemstad, J. O.; Masiello, C. A.; Song,
J.; Peng, P. a.; Mitra, S.; Dunn, J. C.; Hatcher, P. G.; Hockaday, W. C.; Smith, D. M.; Hartkopf-Froder, C.; Bohmer, A.; Luer, B.; Huebert, B. J.; Amelung, W.; Brodowski, S.; Huang, L.; Zhang, W.; Gschwend, P. M.; Flores-Cervantes, D. X.; Largeau, C.; Rouzand, J.-N.; Rumpel, C.; Guggenberger, G.; Kaiser, K.; Rodionov, A.; Gonzalez-Perez, F. J.; Gonzalez-Perez, J. A.; De la Rosa, J. M.; Manning, D. A. C.; LopezCapel, E.; Ding, L. Comparison of quantification methods to measure fire-derived (black/elemental) carbon in soils and sediments using reference materials from soil, water, sediment and the atmosphere. Global Biogeochem. Cycles 2007, 21.

(33) Skjemstad, J. O.; Reicosky, D. C.; Wilts, A. R.; McGowan, J. A. Charcoal carbon in U.S. agricultural soils. Soil Sci. Soc. Am. J. 2002, 66 (4), 1249-1255.

(34) Mao, J. D.; Olk, D. C.; Fang, X. W.; He, Z.; Schmidt-Rohr, K. Influence of animal manure application on the chemical structures of soil organic matter as investigated by advanced solid-state NMR and FT-IR spectroscopy. Geoderma 2008, 146, 353-362.

(35) Glaser, B.; Amelung, W. Pyrogenic carbon in native grassland soils along a climosequence in North America. Global Biogeochem. Cycles 2003, 17, 1064.

(36) Paul, E. A.; Follett, R. F.; Leavitt, S. W.; Halvorson, A.; Peterson, G. A.; Lyon, D. J. Radiocarbon dating for determination of soil organic matter pool sizes and dynamics. Soil Sci. Soc. Am. J. 1997, 61, 10581067.

(37) Anderson, D. W.; Paul, E. A. Organo-mineral complexes and their study by radiocarbon dating. Soil Sci. Soc. Am. J. 1984, 48, 298301.

(38) Liang, B.; Lehmann, J.; Solomon, D.; Kinyangi, J.; Grossman, J.; O’Neill, B.; Skjemstad, J. O.; Thies, J.; Luizao, F. J.; Petersen, J.; Neves, E. G. Black carbon increases cation exchange capacity in soils. Soil Sci. Soc. Am. J. 2006, 70 (5), 1719-1730.

(39) Thompson, M. L.; Zhang, H.; Kazemi, M.; Sandor, J. A. Contribution of organic matter to cation exchange capacity and specific surface area of fractionated soil materials. Soil Sci. 1989, 148 (4), 250-257.

(40) Lee, J. W.; Kidder, M.; Evans, B. R.; Paik, S.; Buchanan, A. C., III; Garten, C. T.; Brown, R. C. Characterization of biochars produced from cornstovers for soil amendment. Environ. Sci. Technol. 2010, 44 (20), 7970-7974.

(41) Cheng, C. H.; Lehmann, J.; Engelhard, M. H. Natural oxidation of black carbon in soils: changes in molecular form and surface charge along a climosequence. Geochim. Cosmochim. Acta 2008, 72 (6), $1598-1610$.

(42) Cheng, C.-H.; Lehmann, J.; Thies, J. E.; Burton, S. D.; Engelhard, M. H. Oxidation of black carbon by biotic and abiotic processes. Org. Geochem. 2006, 37 (11), 1477-1488.

(43) Nguyen, B. T.; Lehmann, J.; Hockaday, W. C.; Joseph, S.; Masiello, C. A. Temperature sensitivity of black carbon decomposition and oxidation. Environ. Sci. Technol. 2010, 44 (9), 3324-3331.

(44) Spokas, K. A.; Cantrell, K. B.; Novak, J. M.; Archer, D. W.; Ippolito, J. A.; Collins, H. P.; Boateng, A. A.; Lima, I. M.; Lamb, M. C.; McAloon, A. J.; Lentz, R. D.; Nichols, K. Biochar: a synthesis of its agronomic impact beyond carbon sequestration. J. Environ. Qual. 2012, 41, 973-989. 